\title{
EXPLORATION OF TRI HITA KARANA ORIENTED LOCAL CULTURE AS A LEARNING RESOURCE FOR FRACTIONS
}

\author{
I Gusti Putu Suharta $1{ }^{\square}$ (D), Ni Nyoman Parwati $2 \square$ (D) \\ 1, 2 Mathematics Education, Universitas Pendidikan Ganesha, Indonesia
}

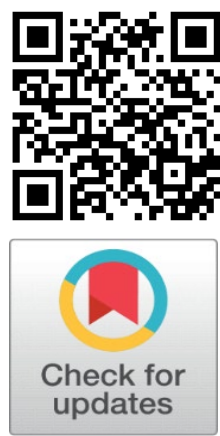

Received 01 December 2021

Accepted 15 December 2021

Published 05 January 2022

\section{CorrespondingAuthors}

Gusti Putu Suharta, putu.suharta@undiksha.ac.id

DOI 10.29121/ijetmr. v9.i1.2022.1086

Funding: This research received no specific grant from any funding agency in the public, commercial, or not-for-profit sectors.

Copyright: (C) 2022 The Author(s). This is an open access article distributed under the terms of the Creative Commons Attribution License, which permits unrestricted use, distribution, and reproduction in any medium, provided the original author and source are credited.

OPEN ACCESS

\section{ABSTRACT}

The use of appropriate learning resources has the potential to improve students' ability in solving mathematical problems. This study aims to determine the local culture that is oriented towards Tri Hita Karana which can be used as a learning resource for fractions in an effort to improve students' problem-solving abilities. This type of research is exploratory with the research subject of the teacher who teaches the fifth-grade students at Elementary School Number 1 Bhaktiseraga Singaraja. Data on aspects of local culture that are oriented towards Tri Hita Karana which can be used as a learning resource for fractions were collected by means of questionnaires and interviews. The results showed that the aspects of local culture oriented to Tri Hita Karana that could be used for learning fractions were the mecaru ceremony, tumpek wariga, odalan, ngayah. These learning resources can be used for material integration or math problems.

Keywords: Local Culture, Learning Resources, Tri Hita Karana, Problem Solving, Fractions

\section{INTRODUCTION}

One of the keywords stated in the vision of Undiksha / faculty / postgraduate / study program is Tri Hita Karana (THK). According to Bawa Atmadja (2020) THK outlines there are three (Tri) causes (Karana) of happiness, namely the harmonious relationship between Parhyangan, Pawongan, and Palemahan. THK does not only exist in humans, but also outside of themselves. THK in humans refers to Atman is Parhyangan, mind is Pawongan, and body is Palemahan. THK is outside of humans, for example, in a traditional village, pretending to belong to a traditional village is Parhyangan, the traditional villager is Pawongan, and the area of the traditional village is Palemahan). The THK also applies to the family (kuren), namely the Sanggah Kemulan is Parhyangan, family members are Pawongan, and the area of the house where they live is Palemahan. In accordance with this opinion, the implementation of THK also applies to classes/schools/campus. Pelangkiran/Pelinggih Padmasana is Parhyangan, students/students are Pawongan, and the classroom/school/campus environment is Palemahan. 
Mathematical problem solving is at the core of learning mathematics. Whatever strategy or approach the teacher uses, the hope is that in the end students will be able to solve the problem. Aspects of local culture will be related to students' realworld knowledge. Suharta and Suarjana (2006), Suharta and Suarjana (2007). state that real-world knowledge about the context of the problem or problem situation involved is needed to see aspects of the problem including mathematical modeling, interpreting the results into the original problem. Bringing local culture into the classroom is a positive thing because students can see the link between local culture and elements of mathematics. The use of local culture that is oriented to THK as a learning resource for fractions material has the potential to develop students' problem-solving abilities. Therefore, it is very important to explore various local cultures that are THK-oriented. Therefore, this study aims to describe a local culture that is oriented to THK which can be used as a learning resource for fractions material in an effort to develop students' ability in problem solving for students of fifth Grade Elementary School Number 1 Bhaktiseraga Singaraja. Fractions material is a part of mathematics material for fifth grade elementary school students.

Mathematics learning resources are defined as anything that can be used to facilitate the learning of fractions. Aspects of local culture that are oriented towards THK, such as the mecaru ceremony, odalan, tumpek wariga, tumpek kandang, and ngayah have the potential to be used as learning resources for fractional.

The Mecaru ceremony can also be called Butha Yadnya, this is a ceremony to maintain harmonious relations between humans and the natural environment, while caru itself means beautiful or harmonious. Pecaruan itself is a pemarisudha Bhuta Kala and all the impurities that exist and hope that everything will disappear and become holy again. (https://dapobas.kemdikbud.go.id/home?show=isidata\&id=955, accessed 27 August 2021)

The Odalan ceremony is a series of Dewa Yadnya ceremonies addressed to Ida Sang Hyang Widi at a temple or holy place. Usually, the odalan procession or big day is led by a holy person such as a stakeholder or priest. Piodalan itself comes from the word "wedal" which means "out" or "born". So, like a birthday celebration, the time of commemoration of the odalan ceremony is designated as the birthday of a temple or sacred building. The purpose of this ceremony is to create a harmonious and prosperous life in society.

Tumpek wariga or Pengatag is one of the Hindu holidays in Bali which is commemorated 25 days before the Galungan holiday which coincides with Saniscara Kliwon Wuku Wariga. There are several meanings contained in the holy day of Tumpek Wariga, namely as a form of worship to Sang Hyang Sangkara which is a manifestation of God which actually means how to maintain nature through plants so that the oxygen needs of all living things can be fulfilled.

Tumpek Kandang is as an insult to pets, besides that the meaning of this ceremony is as a form of gratitude to Ida Sang Hyang Widi Wasa for creating animals that help all the needs of human life, and is meaningful to preserve animals and increase human awareness to further improve affection for animals and their environment Budiawan (2018)

Basically, ngayah is a tradition to help each other to help each other. Ngayah is an obligation for the Hindu community in Bali as the implementation of clan karma. Ngayah comes from the word "ayah, ayahan, pengayah, ngayahang" which has the meaning of being interrelated in a single unit. Ngayah has a larger scale than nguopin (relationships between human beings), but ngayah is a vertical relationship 
with God (https://travel.tempo.co/read/1485458/tangan-ngayah-unjuk-nyatagotong-royong-dan -tolerance-citizens-bali, accessed 27 August 2021)

\section{RESEARCH METHODS}

This study essentially aims to describe aspects of local culture oriented THK that can be used as a learning resource for fractions in an effort to improve students' problem-solving abilities. Therefore, the type of research used is exploratory Ross (2005).

The research subjects were the teachers of Class V SD No. 1 Bhaktiseraga Singaraja who teaches mathematics. There are 2 teachers who teach in class V, both are female sex, civil servant status, one has been teaching in class $V$ for 5 years, while the other has only been teaching in the first semester of class V. To get more comprehensive information, then all teacher at SD No. 1 Bhaktiseraga Singaraja was involved as a respondent, but the results were confirmed to the research subject (class V teacher).

Methods of data collection using questionnaires and interviews. Questionnaires are used to describe aspects of local culture that are THK-oriented which can be used as learning resources for fractional materials, while interviews are used to verify local cultural data. The instruments used are related to data collection methods, namely questionnaires and interview guidelines. The type of questionnaire used is an open questionnaire. Interviews were conducted with fifth grade teachers, to confirm the results of the questionnaire. Furthermore, the data were analyzed descriptively, by first tabulating the data.

\section{RESEARCH RESULTS}

Data on aspects of local culture that are THK-oriented that can be used as learning resources are shown in the following table.

\begin{tabular}{|ccc|}
\hline Table 1 Innovative Learning Resources & \\
\hline Subjects & Learning resources & Frequency \\
\hline Fraction Count Operation & Mecaru, & 5 \\
& Tumpek wariga, & 5 \\
& Odalan & 5 \\
\hline & Ngayah & 5 \\
\hline
\end{tabular}

The results shown from the questionnaire involving 5 teachers were further confirmed to the teachers of class VA and VB. Confirmation is carried out with regard to affirming the use of THK-oriented local cultural aspects that can be used as a source of innovative learning related to the material, as well as how it can be used as a learning resource. Confirmation is done through a structured interview via video call. Aspects of local culture that are THK-oriented that can be used for learning fractions counting operation materials are the mecaru ceremony, tumpek wariga, odalan, ngayah. 


\section{DISCUSSION}

The knowledge that is expected after students learn the material for counting fractions in fifth grade elementary school is to explain and do the addition and subtraction of two fractions with different denominators. Aspects of local culture that are oriented towards THK as an innovative learning resource for fraction counting operations are the mecaru ceremony, tumpek wariga, odalan, and ngayah.

Mecaru is a ceremony that can be taken half or several parts of the ceremony or when making caru can be divided. The facilities in the mecaru ceremony can be used in terms of fractions, for example using $1 / 2$ chicken from the whole chicken used for the mecaru ceremony, as well as the fruits used in the ceremony, fractional addition operations can be used by applying the smallest common multiple to equate the denominator.

In addition, at the mecaru ceremony, when it is associated with fractional counting, there are elements that can be linked/used in teaching fractions. For example, mother has 1 plate of rice which will be used to make caru, 1/2 part of it will be used to make yellow rice, $1 / 4$ of it will be used to make brown rice. The rest is for white rice. How much rice will be used for the white color?

Tumpek wariga day is a ceremony to pay homage to plants. In preparation for this ceremony will use various fruits. For example, my mother went to the market to buy $1 / 2 \mathrm{~kg}$ of pine apple and $2 / 3 \mathrm{~kg}$ of guava. How many mothers buy fruit for the tumpek wariga ceremony? Therefore, the material for counting fractions operations can be related to learning resources oriented to Tri Hita Karana in the process of the tumpek wariga ceremony.

Odalan can also be used as a THK-oriented innovative learning resource. For example, my mother buys fruit to prepare odalan so she buys $2 / 4 \mathrm{~kg}$ of oranges, $1 / 4$ $\mathrm{kg}$ of apples, and $1 / 4 \mathrm{~kg}$ of grapes. How many mothers buy fruit for odalan? Therefore, the material for fractional arithmetic operations can be linked to learning resources oriented to Tri Hita Karana in the odalan process.

Ngayah is a community activity that can be used as a THK-oriented innovative learning resource. All the people who attend the ngayah can be divided into several groups and each group is given a specific task. In addition, during the operation of counting fractions, it can also be used to determine what percentage of the participants cleared a certain location, etc.

\section{CONCLUSIONS}

The local culture oriented to Tri Hita Karana that can be used as an innovative learning resource for learning fractions counting operations material, is the mecaru ceremony, tumpek wariga, odalan, ngayah. These learning resources can be used for the development of students' abilities in solving mathematical problems.

Other researchers are advised to develop innovative learning resources by using aspects of local culture such as mecaru, odalan, tumpek wariga, tumpek kandang, ngayah in an effort to develop students' mathematical problem-solving abilities for the better. 


\section{REFERENCES}

Bawa Atmadja. (2020). Postgeneric Discourse on Tri Hita Karana in Balinese Society.Depok. Rajawali Press

Dopang Budiawan. (2018). The Philosophical Meaning of the Tumpek Kandang Ceremony and Environmental Harmony in the Cosmos System in Sangkan Pakraman Village, Mount Karangasem. Journal of Religious Science, 1(1), pp.19-35

Hiebert, J and Carpenter, T. (1992). Learning and Teaching With Understanding. Handbook of Research on Mathematics Teaching and Learning. New York : Macmillan Retrieved from https://books.google.co.in/books?hl=en\&lr=\&id=N_wnDwAAQBAJ\&oi=fnd \&pg=PA65\&dq=Learning+and+Teaching+With+Understanding.+Handbook +of+Research+on+Mathematics+Teaching+and+Learning\&ots=zk0vftxFY M\&sig=mf8k7_n973W6S1Ermz7ytwyfTW0\&redir_esc=y\#v=onepage\&q=L earning\%20and\%20Teaching\%20With\%20Understanding.\%20Handbook \%20of\%20Research\%20on\%20Mathematics\%20Teaching\%20and\%20Le arning\&f=false

Kenneth N. Ross. (2005). Quantitative research methods in educational planning. Paris : International Institute for Educational Palnning/UNESCO

Ministry of Education and Culture (2018). Teacher's Book Enjoys Learning Mathematics in Elementary/MI Class V. Jakarta : Ministry of Education and Culture.

Novotna. (2000). "Students' Levels of Understanding of Word Problems". Paper presented at ICME-9, July 31 - August 6, 2000. Tokyo : - Retrieved from https://link.springer.com/chapter/10.1007\%2F1-4020-7910-9_43

Permendikbud No. 24 of (2016) concerning Core Competencies and Basic Competencies of Lessons in the 2013 Curriculum.

Saliman. (2007). Application of Culture-Based Learning as an Effort to Improve the Quality of Learning in Lesson Planning Courses. Paper presented at the National Seminar on Learning Innovation, with the theme: "Improving the Professionalism of Prospective Teachers and Teachers through Innovation"Learning". Jakarta.

Sardjiyo and Paulina Pannen. (2005). Culture-Based Learning : Learning Innovation Model and Implementation of Competency-Based Curriculum. Journal of Education.6(2) : 83-98

Suharta and Suarjana. (2006). Development of Realistic Mathematics Learning Tools for Elementary School Students Oriented to Problem Solving, Reasoning, and Communication. The Research Report (Phase I) was not published. Singaraja : Undiksha

Suharta and Suarjana. (2007). Development of Realistic Mathematics Learning Tools for Elementary School Students Oriented to Problem Solving, Reasoning, and Communication. The Research Report (Phase II) was not published. Singaraja : Undiksha 
Suharta, Sadra, and Gita. (2008). Application of Mathematics Learning with Cultural Environment as an Effort to Improve Basic Competence for Elementary School Students. The research report is not published. Singaraja : Undiksha

Suharta. (2002). Case Study on Realistic Mathematics Problem Solving Ability for Elementary School Teachers in Singaraja. Research Report is not published. Singaraja : Singaraja State IKIP

Suharta. (2016). "Ability of Elementary School Students in Solving Real Mathematics Problems". Journal of Education and Teaching, 49, Number 3, October 2016, pp.137-147

Van den Heuvel-Panhuizen. (2000). Mathematics Education in the Netherlands a Guided Tour. (Online). Retrieved from Http://www.fi.uu.nl/en/indexpulicaties.html 